\title{
A WORLD WIDE EMERGENCY PROGRAMME FOR THE CREATION OF NATIONAL GENEBANKS OF ENDANGERED BREEDS IN ANIMAL AGRICULTURE
}

\section{E. Groeneveld}

\begin{abstract}
Summary
In response to the rapid loss of animal genetic resources, a world wide emergency program is proposed to create national genebanks on the basis of somatic cells. Contrary to other procedures, like storing deep frozen semen or embryos, collection and storage of somatic cells can be done cheaply and rapidly for any species. Only in this way can an emergency store of animal genetic resources be created fast enough to forestall the outgoing rapid erosion of animal biodiversity. While animals can already be produced from somatic cells for 10 species, this number will continue to rise in the future. A layered strategy is proposed which is based on collection and storage within individual countries, thus leaving execution of the program, responsibility and ownership of these national cryobanks with those countries. After a pilot study, more country genebanks could be created as funds become available. With a limited effort, the creation of a network of national genebanks of last resort are a realistic option.
\end{abstract}

Key words: somatic cells, genebank, cryogenic conservation, animal genetic resources, conservation programmes, endagered breeds, data base, FAO.

\section{Introduction}

Since the Convention on Biological University (United Nations, 1992), conservation of genetic variability has become a generaly accepted responsibility of United Nations member states. While developed countries have taken on the responsibility, and have the means, to preserve their endangered breeds in the area of animal agriculture thereby reducing the rate of extinction, breeds are still disappearing on a global level at a worrying rate (Scherf, 2000). As a result, the Food and Agricultural Organization (FAO) of the United Nations has set up the Animal Genetic Resources Group to develop a strategy for the management and utilisation of animal genetic resources.

E. Groeneveld, Institute for Animal Breeding. Federal Agricultural Research Center, Mariensee. D-

31535 Neustadt, Germany.

Paper presented at AGRI 2005, 36: 1-6. 
Many of the activities were geared towards the creation of infrastructure in member countries with the objective, amongst others, to create awareness about the importance of animal genetic resources. National coordinators for animal genetic resources are responsible within countries for their national genetic resources. The development of the global strategy created the Domestic Animal Diversity lnformation System (DAD-IS http://dad.fao.org) as an international information exchange platform, that, based on the EAAP breeds database, presents an overview of the breeds of the world.

\section{The Rational for Using Somatic Cells in Cryogenic Conservation}

Clearly, utilization and improvement of local breeds would be the best means of conservation. However, the dynamics driving population development in many parts of the world are different, and is often achieved by replacing local breeds by exotic genetics imported from the first and second world. While the indiscriminate replacement of local breeds with these high input, high yielding breeds may not be sustainable in many instances, they will continue to replace local populations where the 'environment' in terms of management, housing and feeding can also be imported. With progressing urbanization this process is and will be very rapid. As a result, it will be very difficult to counteract the replacement and the implicit loss of local breeds. The World Watch List demonstrates impressively the need to counteract this development (Scherf, 2000).

There are a number of options for conservation when used in its broadest sense:

1. conservation through utilization and improvement;

2. in-vivo conservation;

3. in-vitro conservation.

As is generally known, the three strategies serve very different objectives and are also very different in terms of costs and effort required. Improvement and utilization is a long term process. Setting up breeding programs has taken many decades to develop in Europe, a time frame that will also have to be expected for many parts of the world where they are intended to be developed. Thus, this option is not suited to counteract the rapid decline in population sizes which will take place in the meantime. 
In-vivo conservation of endangered breeds requires subsidies that make up for the financial difference to competing breeds. While this may be affordable in the developed world, it is not an option in many developing countries.

This leaves us with the in-vitro conservation. Traditionally, it comprises material like semen, embryos and perhaps oocytes. Placement in liquid nitrogen allows unlimited storage, while recovery is relatively straight forward. There are however a number of reasons, why these techniques cannot generally be used for endangered breeds world wide. Deep freezing of semen and embryos can be done for a number of species only. Furthermore, it requires substantial infrastructure in the countries which is not generally available, not to mention considerable costs, an issue also pointed out by Woolliams and Wilmut (1999). As a consequence, this is also not an option.

We need to develop a strategy which can be deployed quickly because breeds are being lost continually, is sufficiently cheap and is simple enough to be carried out in parts of the world with little infrastructure. Here, storage of somatic cells may open an option as pointed out by Corley-Smith and Brandhorst (1999).

Somatic cells can be collected from every animal; either a skin or ear notch or blood can be used. In this way the collection of samples can he cheap and fast. Tissue samples can be cryo-conserved in liquid nitrogen easily. Collecting a sufficiently large number of samples is thus also a distinct possibility even in those countries with little infrastructure.

Under an in-vivo conservation scheme live animals are available for utilization, where semen and embryos are a proven path to reconstitute a breed, albeit a time consuming and costly one. While this is not as straight forward with somatic cells, a new path is developing rapidly via cloning. Already now it is possible to reconstitute an animal from basically every sample of somatic cells (to date demonstrated for 10 species). Currently, this process is very costly, but this is expected to change in the future.

The question about which strategy to pursue in the conservation of endangered breeds basically narrows down to these alternatives:

1. Traditional conservation means; and

2. Somatic Cell Cryo Conservation (SCCC)

\section{Traditional conservation means}

In-vivo conservation via breed improvement programs will not stop breed loss in many parts of the world where currently breeds are disappearing. The 
reason far not being able to turn the tide against breed loss via breed improvement programs is that an infrastructure will have to be created first. This requires a large financial investment but more importantly time, which is running out. Thus, even if money were available to set up improvement programs (management and genetic), by the time this has an impact on the population, many breeds would have disappeared. (Having said this, wherever possible breed improvement programs ought to be developed, but relying on them as a means to preserve breeds will in many instances fail.)

Also, cryo-preservation using semen and/or embryos is no option for the same reason. Firstly, this technique also requires substantial infrastructure including human investment which is always a lengthy process. Furthermore, cryo-preservation is not possible for certain species. Even where it would be technically possible, the sheer time it takes to perform the tasks will make it impossible to acquire samples from sufficient numbers of animals rapidly enough.

\section{Somatic Cell Cryo Conservation (SCCC)}

The tissue collection phase is short and simple. Once an animal has been located and restrained, a tissue sample like an ear clipping can be collected within seconds. Furthermore, somatic cells can be collected from all species. The samples can be stored initially in cooling boxes until moved to a tank containing liquid nitrogen. Using this strategy, harvesting a sufficiently large number of samples from a large number of breeds of different species can be done in a limited time with limited funds. The most important issue is knowing where the animals are and which samples are to be taken.

Admittedly, SCCC has limited scope as regards reconstitution of animals at this paint in time. If the objective is to save something that would otherwise be last and is considered potentially very important in the future, but without knowing if it will be utilized, then SCCC provides a possibility to do something. The question to be answered is then: do we rather want to have no samples (or very few) in store from the semen/embryo category or complete coverage (which could be achieved with same effort) of somatic cells that may be difficult to reconstitute now (although even that is possible) but will become much easier in all likelihood in the future. The logical conclusion is very clear: the only option to create a genetic backup for many endangered breeds at this time is via SCCC. Thus, a global program should be developed as soon as possible to create national SCCC banks preferably under the umbrella of FAO AGAP. 


\section{Technical Issues for SCCC}

A large number of tissues can be used as the starting material for SCCC, such as blood, skin samples and tissues from ears. For cattle, pigs, sheep, goats, camelids and llamas, a unified and identical procedure can be used by obtaining a tissue sample from the ear using notchers which are also used for setting earmarks (e.g. wwv.biopsytec.de). Clearly, for all species lymphocytes could be used, but somatic cells from ear clippings will be much easier to obtain and are therefore preferable.

The complete process from an animal via deep frozen somatic cells to its reconstitution by cloning comprises the following steps ( $\mathrm{Niemann}$, personal communication, 2003): 1. Collect samples:

a. identify animal as sample source;

b. take tissue sample, for instance using an ear notcher;

c. place the plastic vila containing the tissue sample into the cooler;

d. record the vial number plus all info required for the animal;

e. go back to the centre where the deep freezer (liquid nitrogen) is located;

f. put all samples into the freezer and record their location;

g. enter data into database.

Use samples for genotyping/cloning:

a. take somatic cell sample from the freezer;

b. thaw;

c. create and cultivate fibroblast culture (i.e. multiplying the tissue material);

d. take sample from the fibroblast culture for use;

e. freeze the rest (this process can be repeated).

To date, creating clones from somatic cells has been successful for 10 species, three having been added only during the year 2003 (Kues and Niemann, 2004). Therefore, it can be expected that this procedure will be available in the future also for those species where cloning thus far has not been done or has not been successful.

If ear notchers are used for sampling the tissues, the tagging process will place the sample automatically into a small plastic vial. Then these samples need to be put into cooling boxes until they are stored later into more permanent 
containers in liquid nitrogen at a location to be determined by the member country.

Without individual documentation the samples stored will be useless. Thus a system needs to be readily available to facilitate bookkeeping and identification of each tissue sampled stored. A minimum set of data elements should be recorded allowing a uniform documentation of a samples world wide. Data collected comprises: species, breed, location, tissue type, location within the liquid nitrogen tank. Currently, development of generic genebank information systems are under way (Groeneveld et al., 2004) that would be available for this documentation, including free exchange of data, perhaps as part of an expanded DAD-IS data structure.

\section{The Within-Country Strategy}

Animal genetic resources are the responsibility of individual countries. Therefore, development of conservation programs should also be done by each countries. Only there is the knowledge about the location and the breeds under threat readily available. Therefore, countries need to identify which breeds they want to put into cryo-conservation. In this way the ownership of the samples also remains clear, they belong to the country of origin. Accordingly, samples are best stored within the country itself. Collection of samples is relatively straight forward with limited demands on resources. The storage facilities are somewhat more costly but more importantly, do require a constant and secured supply of nitrogen or electricity for the deep freezer. Perhaps this cannot be guaranteed everywhere. Where this is not possible, one might consider undertaking contractual cooperation with neighbouring countries that are in a somewhat safer position. Such a solution could be temporary.

\section{Expanding to a Global Program}

Over recent years, FAG-AGAP has created a remarkable infrastructure at the national and regional level through their national and regional coordinators for animal genetic resources. It has lobbied heavily to create awareness about their importance. While inroads have been made in this area, the decrease in breed numbers has not been halted.

Initiating actual classical conservation programs in member countries is close to impossible because of the costs and the organizational issues involved. With the new possibilities that SCCC creates, the situation has changed. Given the limited amount of funds required and the infrastructure created by FAO, the 
conditions are really very good to try to create a global initiative for the setup of country based SCCC in a relatively short time.

\section{An Initial Pilot Program}

The FAO-AGAP could be the promoter, coordinator and executor of this program. An initial pilot program should concentrate on the verification of the collection and storage procedures. It would be preferable if this was undertaken with one country only. The experience gained would result in guidelines to be used for the much broader action to follow. The issues to be dealt with are:

- identification and testing of tissue collection procedures for each species, where it is probable broad groupings can be made such as mammals and birds;

- verifying the procedures for the creation of fibroblast cultures from the sampling procedure used;

- work. flow from identification of animals to be sampled, initial recording of relevant information on sire, intermediate storage of samples;

- placement in final cryo-store;

- finalizing a cryo-database, setup and training;

- entering information in national database with connection to DAD-IS.

\section{Expansion to Global Action}

After the pilot project has been carried out and evaluated, the program can be expanded through other countries using the FAO AGAP infrastructure. If it not possible to secure funding for the complete worldwide program in one block, the program can get started and then expand as funds become available.

\section{Costs and Time Frame}

Due to the fact that only somatic cells are being collected with a robust technology, the cost for even a global program will be limited. The largest block of start up costs for physical equipment for the execution of this program with in a country is for the cryogenic tank which is in the order of $\$ 700$. Then there will be costs for a cooling box plus the notcher. Thus, the total investment in this area is in the order of $\$ 1,000$ per country. The biggest costs will be travel and personnel which increase in direct proportion to the number of samples 
taken. As stated before, one of the biggest advantages of this procedure is that it can produce results very much faster than any other. Given that funds are available and the operational procedures established, an emergency backup of a country's animal genetic resources in the form of a somatic cell cryoconservation bank could well be established within a year or so. Together with the relatively low costs, this fact may turn out to be a very persuasive argument to convince potential donors.

\section{REFERENCES}

1. Corley-Simth, G.E. \& B.P. Brandhorst (1999): Preservation of Endangered Species and Populations: A Role for Genome Banking, Somatic Cell Cloning, and Androgenesis? Molecular Reproduction and Development, 53: 303-367.

2. Groeneveld, E., L. Yordanova, \& S.J. Hiemstra (2004): Organizational Structure and Information Technological Support of National Gene Banks. Livestock Production Science. 89: 297-304

3. Kues, W.A. \& H. Niemann (2004): The contribution of farm animals to human health.

4. Scherf, B.D. (Ed.) (2000): World Watch List for domestic animal diversity. Food and Agricultural Organization on the United Nations, Rome. Italy, 3rd edition.

5. United Nations (1992): United Nations Environment Program Convention on Biological Diversity. http://dad.fao.org/en/refer/library/conventn/cbd.pdf

6. Woolliams, J.A. \& I. Wilmut (1999): New advances in cloning and their potential impact on genetic variation in livestock. Animal Science, 68: 245-256.

\section{NUŽNI GLOBALNI PROGRAMI ZA STVARANJE BANAKA GENA UGROŽENIH PASMINA ŽIVOTINJA U POLJOPRIVREDI}

\section{Sažetak}

Zbog naglog gubitka životinjskih genetskih resursa nužan je globalni program za stvaranje banaka gena na temelju somatskih stanica. Za razliku od drugih postupaka kao što je spremanje duboko zamrznutog sjemena ili embrija, skupljanje i spremanje somatskih stanica bilo koje vrste može se obaviti jeftino i brzo. Jedino se na taj način može stvoriti nužna zaliha životinjskih genetskih resursa dovoljno brzo da se zaustavi trenutno naglo propadanje životinjske bioraznolikosti. Već sada se može proizvesti iz somatskih stanica 10 vrsta životinja a taj će broj i dalje rasti u budućnosti. Predlaže se postupna strategija koja se temelji na prikupljanju i spremanju u pojedinim zemljama i tako ostavlja izvršenje programa, odgovornost i vlasništo tih nacionalnih cryobanaka tim zemljama. Nakon pilot studije može se stvoriti više banaka gena u zemljama prema dostupnim fondovima. Ograničenim trudom stvaranje mreže nacionalnih banaka gena realan je izbor.

Ključne riječi: somatske stanice, banka gena, cryogensko očuvanje, životinjski genetski resursi, programi za očuvanje ugroženih pasmina, procjena troškova, baza podataka, FAO. 